\title{
Research as freedom: Using a continuum of interactive, participatory and emancipatory methods for addressing youth marginality
}

\begin{tabular}{|c|c|}
\hline \multicolumn{2}{|c|}{$\begin{array}{l}\text { Authors: } \\
\text { Sharlene Swartz' } \\
\text { Anye Nyamnjoh }{ }^{1,3} \text { — }\end{array}$} \\
\hline \multicolumn{2}{|c|}{$\begin{array}{l}\text { Affiliations: } \\
{ }^{1} \text { Human and Social } \\
\text { Development Research } \\
\text { Programme, Human Sciences } \\
\text { Research Council, } \\
\text { South Africa }\end{array}$} \\
\hline \multicolumn{2}{|c|}{$\begin{array}{l}{ }^{2} \text { Department of Philosophy, } \\
\text { University of Fort Hare, } \\
\text { South Africa }\end{array}$} \\
\hline \multicolumn{2}{|c|}{$\begin{array}{l}{ }^{3} \text { Politics and International } \\
\text { Studies, University of } \\
\text { Cambridge, United Kingdom }\end{array}$} \\
\hline \multicolumn{2}{|c|}{$\begin{array}{l}\text { Corresponding author: } \\
\text { Sharlene Swartz, } \\
\text { sharlene.swartz@gmail.com }\end{array}$} \\
\hline \multicolumn{2}{|c|}{$\begin{array}{l}\text { Dates: } \\
\text { Received: } 01 \text { May } 2018 \\
\text { Accepted: } 22 \text { Aug. } 2018 \\
\text { Published: } 18 \text { Oct. } 2018\end{array}$} \\
\hline \multicolumn{2}{|c|}{$\begin{array}{l}\text { How to cite this article: } \\
\text { Swartz, S. \& Nyamnjoh, A., } \\
\text { 2018, 'Research as freedom: } \\
\text { Using a continuum of } \\
\text { interactive, participatory } \\
\text { and emancipatory methods } \\
\text { for addressing youth } \\
\text { marginality', HTS Teologiese } \\
\text { Studies/Theological Studies } \\
\text { 74(3), a5063. https://doi. } \\
\text { org/10.4102/hts.v74i3.5063 }\end{array}$} \\
\hline \multicolumn{2}{|c|}{$\begin{array}{l}\text { Copyright: } \\
\text { (C) 2018. The Authors. } \\
\text { Licensee: AOSIS. This work } \\
\text { is licensed under the } \\
\text { Creative Commons } \\
\text { Attribution License. }\end{array}$} \\
\hline \multicolumn{2}{|l|}{ Read online: } \\
\hline 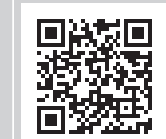 & $\begin{array}{l}\text { Scan this QR } \\
\text { code with your } \\
\text { smart phone or } \\
\text { mobile device } \\
\text { to read online. }\end{array}$ \\
\hline
\end{tabular}

Authors:

Affiliations:

${ }^{1}$ Human and Social Development Research Programme, Human Sciences Research Council,

South Afric

${ }^{2}$ Department of Philosophy, University of Fort Hare,

Cambridge, United Kingdom

Corresponding author:

Sharlene Swartz,

Dates:

Received: 01 May 2018

Accepted: 22 Aug. 2018

How to cite this article: Swartz, S. \& Nyamnjoh, A. 2018, 'Research as freedom: Using a continuum of interactive, participatory and emancipatory methods for addressing youth marginality, HTS Teo 74(3), a5063. https://doi. .4102/hts.v74i3.5063

Copyright:

Licensee: AOSIS. This work

is licensed under the

Creative Commons

Attribution License.

mobile device to read online.
This article offers an analysis of a continuum along which interactive, participatory and emancipatory inquiries may be placed in critical qualitative research with a social justice focus. It draws on critical distinctions to make the argument that labelling research 'participatory' hides both interactive approaches and those that might be seen to be emancipatory in the vein of Paolo Freire and Stanley Biggs. To support the argument for a continuum of engaged research, four recent research studies from South Africa, Cameroon, Nigeria and Sierra Leone that address youth marginality and views on an array of topics are discussed with a view to articulating divergences and convergences in approaches. Included are considerations around adapting research for specific audiences and participants, the location of power, research ethics, as well as the demystification and democratisation of knowledge ownership and generation, and the nature of collaboration. The article offers tentative criteria by which research may be located along the suggested continuum and argues that an emancipatory approach, whilst being key to bringing about change or freedom, is a difficult but not impossible aim to achieve in research.

\section{Introduction}

Research does not always change people's lives, nor does it frequently bring about freedom. In fact, the opposite is more regularly true: research can be intrusive, extractive and self-serving. However, research conducted with the aim of promoting social justice is possible and forms a part of the research endeavour amongst many scholars and activists. Usually, when we think about research with such an impact, it is participatory research that comes to mind, with its emphasis on the practicality of knowledge production and the cultivation of partnerships between researchers and those researched. Such a view obscures a spectrum of inquiries, such as interactive and emancipatory research which have varying impacts when producing knowledge on social justice and marginality. As such, how can we, from a methodological perspective, talk about research that changes people's lives and brings about freedom in a way that recognises these multiple forms of inquiry and their varying impacts?

In this article we describe a continuum along which interactive, participatory and emancipatory inquiries may be placed in research with a social justice focus. Using a literature review and four case studies which focus on various elements of youth marginality as well as young people's beliefs about justice and faith, we interrogate how this continuum might be characterised and the different impacts these different types of inquiry possess. We argue that as we move from interactive to emancipatory research, we attain higher degrees of ownership of the research by the stakeholders whose lives are affected by the problem being studied. These higher levels of ownership represent a process in which research is transformed by the reallocation of power between researcher and researched until the point where the traditional researcher simply retains only the role of facilitator. In the final analysis, interactive research is owned by the researcher, whilst participatory research is owned by both researcher and the researched. In emancipatory research, the research belongs to the researched. Put simply and from the perspective of the traditional researcher, ownership or power along this continuum transitions from mine to ours to theirs. Mapping out this continuum enables researchers to better describe and evaluate where their work currently is and where they would like it to be in the future and to ask the right questions in order to get there.

\section{An overview of the literature on interaction, participation and emancipation}

Scholarship on interactive, participatory and emancipatory research is quite prominent (yet by no means in agreement or systematic) in a number of fields. These include disability studies, youth 
studies, nursing, social work as well as policy research and development. What follows is an overview of the key features of each of the words 'interaction', 'participation' and 'emancipation' as it relates to research.

\section{Interaction}

The academic literature describes interactive research in varied ways. Its most simple definition includes engagement through a series of activities with research participants. For example, these can include a wide array of activities beyond usual 'talking methods' such as interviews and focus groups, to include photovoice, photo-elicitation, working with family photos, cinematic texts, video production, material culture, advertising campaigns, archival work, collage, drawings, performance, community mapping (Mitchell 2008) and other creative ways of allowing people to 'tell their lives'. However, most scholars when speaking of interactive methods tend towards describing interactive research as synonymous with participative research. For example, Astleithner and Hamedinger (2003:627) describe interactive research as 'a research process, in which "researchers" and "practitioners" develop knowledge for solving problems in a communicative, reflexive and collaborative way'. According to Svensson et al., 'The interactive researcher participates, but does not observe in a traditional and remote way. Instead of participative observation we can talk about participative experience' (2007:261). There is broad consensus that interactive research involves mutual knowledge building, co-operation and long-term dialogue with the people with whom researchers work. Furthermore, there is a continued process of data analysis with the participants. It is also a selfcritical, reflective practice (Albinsson \& Arnesson 2010; Amble 2012; Svensson et al. 2007) and requires enduring relationships based on effective two-way communication (Gustavsson 2009; Kelly \& Moles 2002). Interactive research is generally seen as having its origins in educational action research and some claim it is an aspect of action research (Albinsson \& Arnesson 2010; Svensson et al. 2007).

\section{Participation}

Participatory research is variously defined as an approach to research founded on an egalitarian relationship between researcher and researched. In so doing, it challenges the relationship of domination that tends to characterise research, wherein the researcher is typically in control of the production and dissemination of knowledge. As such, it calls for the inclusion or participation of stakeholders whose everyday lives are affected by the problem under investigation (Cook 2008). What is imagined here is the 'co-construction of research between researchers and people affected by the issues under study' (Jagosh et al. 2012:312). Taking this into consideration, research is reimagined as a subject-subject relationship, as opposed to a subject-object relationship. Research is conducted with those affected, rather than on those affected (e.g. like research conducted on laboratory rats). Participatory research is also linked with empowerment because it tries to bridge the gap between intellectual knowledge and social action in order to empower impacted parties to become agents of change (Amendola 2011:82).

The appeal of participatory research lies in a number of aims and outcomes, notably the inclusion of minorities in research and interventions (Cook 2008; De las Nueces et al. 2012; Nadimpalli \& Hutchinson 2012; Salimi et al. 2012). In addition, research is tailored to the needs of the people researched, enhancing the validity and relevance of the study (Bangdiwala et al. 2012; Cook 2008:674). Moreover, this is seen to promote the quality and scope of data because it is needs oriented (Salimi et al. 2012). Participatory research is also co-governed with equitable input (Cook 2008; Jagosh et al. 2011). Community members are collaborators and engaged as partners, not subjects (Bangdiwala et al. 2012; De las Nueces et al. 2012). This is conducive to community empowerment (Amendola 2011; Salimi et al. 2012) and a commitment to capacity building as part of the process (Cook 2008). In addition, it shows the location of power as a key feature, underpinned by a commitment to the democratisation and demystification of scientific research. Furthermore, it is action-orientated, because of the integration of research and action (Cook \& Fonow 1986; Salimi et al. 2012; Watts 2006). In addition, participatory research (including communitybased participatory research) is seen to allow for additional insights during the research process which 'enhance the understanding of a given phenomenon and the social and cultural dynamics of a community' (Cook 2008:668).

\section{Emancipation}

Evolving from critical theorists, emancipation became a central tenet of critical social science and feminist approaches as a result of the acknowledgement of oppression and the desire to engage in political action to create change (Rose \& Glass 2008). Critical theory is based on the premise that knowledge must be practical and that with knowledge comes empowerment, the lifting of oppression, which in turn allows the full attainment of humanity. Feminist theory 'often deploys critical theory in analysing interlocking systems of power and domination through intersectional analysis of the conditions and experiences of women' (Kagan et al. 2009:78). A number of broadly agreed upon characteristics seem to define emancipatory research. The traditional researcher plays a facilitative role as opposed to a controlling one by providing methodologies and skills (Garbutt 2009) and provides a 'forum where analysis, reformulation, and recognition of emancipatory interests are supported and encouraged' (Alexander 2010:603). Furthermore, a central concern of emancipatory research is power and oppression. It acknowledges that because 'all relationships involve imbalances of power, exposing these power relations in personal and social contexts is an overarching goal of these approaches' (Irwin 2006:95). Thus, emancipatory research aims to improve the existing social and material relations of research production (Oliver 1992; 1997). For the process to be truly freeing, 'the participant researchers must self-identify a reformulation of the situation which supports their interests and removes imbalances' (Alexander 2010:604). 
It also has empowerment as an objective which is anchored in the moral right of the marginalised to own and control knowledge produced about them (Baker et al. 2004). The definition of topic, data collection, data analysis and dissemination are driven by research participants to serve their needs, rather than that of the researcher. A process of empowerment occurs when the 'oppressed' group gains power in, and maintains control over, the research process (Alexander 2010; Danieli \& Woodhams 2005; Garbutt 2009; Irwin 2006). As such, emancipatory research gives voice to the oppressed (Garbutt 2009). Another key feature is the understanding of knowledge as emancipatory or able to bring about freedom. This is part of a radical social agenda of equality (or justice) where research and knowledge production focus on the oppressed and the voiceless, aiming for self-determination, sovereignty and the transference of research ownership. It is in this vein that Paolo Freire outlines the linkages between knowledge and emancipation. He advocated conscientisation and dialogue amongst the poor and oppressed about the conditions of oppression, so they are better able to name their world and its oppressions, and thus transform it (Freire 2000). Subsequently, the development of a critical consciousness allows the oppressed to 'perceive the reality of oppression not as a closed world from which there is no exit, but as a limiting situation which they can transform' (Freire 2000:49).

\section{Towards an intentional continuum of research methods}

The usefulness of framing research as freedom along a continuum lies in the observation that the distinction between emancipatory and participatory research and between different interpretations of interactive research is not always clear, with the terms frequently being used interchangeably (Walmsley 2001). This is evident when we consider scholarship that attempts to describe what constitutes genuine participation, such as Cornwall and Jewkes' (1995) contrast between 'deep' and 'shallow' participation or Hart's (1992) 'ladder of participation' wherein the bottom rung represents manipulation whilst the top rung represents equity. What we end up seeing is that understandings of genuine participation are almost always congruent with emancipation. A further example is the modes of participation described by Stanley Biggs (1989), which include contractual, consultative, collaborative and collegiate participation. Summarising these differences, Aldridge (2015) notes:

Contractual participation involves a simple arrangement in the 'researcher-researched' relationship whereby participants are contracted into studies in order to extract data; participants engaged in the consultative mode are involved in consultation processes about research projects prior to their implementation; the collaborative mode involves researchers and participants working together in research processes, although projects are designed and managed by researchers themselves; and the collegiate mode is fully consultative and inclusive, with an emphasis on mutuality in terms of the planning, management and ownership of the research project (p. 2, [author's own italics])
Emancipation is often seen as an ideal outcome, or simply part of the process, of participatory approaches to research, including action research (Alexander 2010; Macdonnell 2011; Maginess 2010; Nugus et al. 2012). Perhaps this misperception stems from a deeper confusion around the concepts of emancipation and empowerment, which are both closely connected to a 'participatory worldview' in which, according to Boog 92003), it is understood that:

all people must be equal participants in society, which means that they must have equal opportunities for schooling and jobs, have the opportunity to share in all goods and services in society and participate in decision-making, both public and private. (p. 427)

In disability research Zarb (1992) makes an argument for the distinction between participatory and emancipatory research. Walmsley (2001) provides a useful summary of Zarb's distinctions, which include differences in methodology, ideology, loci of control and the role of the researcher.

Another motivation for the construction of a continuum is the observation that interactive research, participatory research and emancipatory research share a number of similar characteristics that are also persistently conflated. These include the application of knowledge, which stands in contrast to a positivist approach where research is no more than data collection. In addition, they share a commitment to mutual and sustainable learning, self-reflection, the coconstruction of knowledge and the empowerment of research participants. Fundamentally, they share a commitment to inclusivity and engagement in the research process. What the continuum does is to suggest differentiating these methods as forms of inquiry with varying degrees of inclusion, power and ownership.

We would further suggest that emancipatory inquiry is the ideal kind of research to which to aspire if the goal is justice and freedom. In interactive research, inclusion is modest, and the researcher retains power and ownership of the research. Participatory research is characterised by greater inclusion, shared power and ownership, whilst in emancipatory research the researcher relinquishes power and ownership, and inclusion is a sine qua non and changes as the process proceeds. Consequently, as we move from interactive to participatory and finally emancipatory inquiries, the research, from the perspective of the traditional researcher, transforms from mine to ours to theirs (see Figure 1 for a graphic depiction).

\section{Interactive methods}

Furthermore, in using interactive methods, the researcher will incorporate activities within the research design to create a space for participants' voices to be heard and thus be included in the research. However, within this continuum, this is only 'participation lite' inasmuch as these activities are chosen by the researcher and are in service of a research design driven by the researcher. This is in tandem with what 


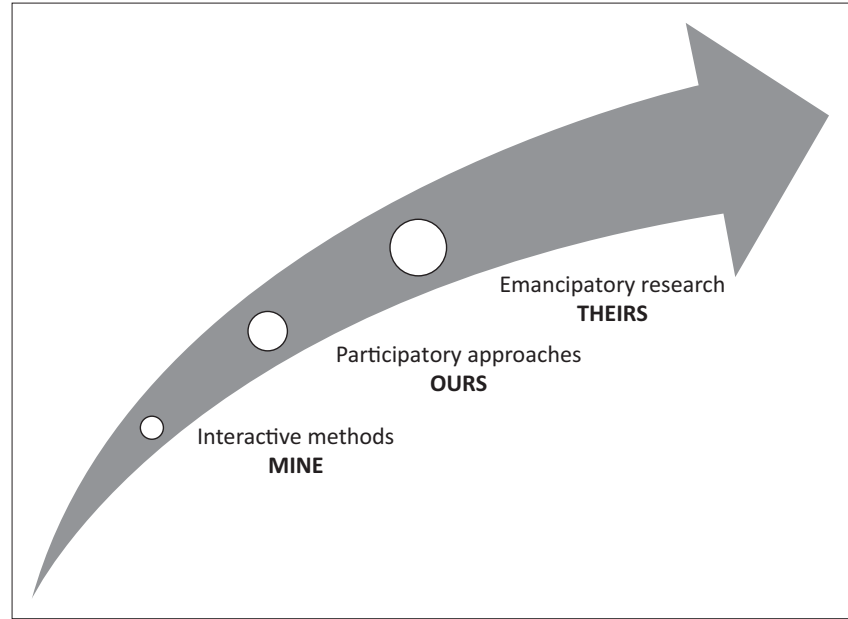

FIGURE 1: A proposed continuum of research methods.

Cornwall and Jewkes (1995:1669) describe as 'shallow participation', which stands in contrast to 'deep participation' which moves towards transferring ownership. Nonetheless, a notable outcome here is the creation of a space for polyphonic voices and parallax perspectives. The relationship between power and ownership is such that in the final analysis, the research is owned and controlled by the traditional researcher. However, in using interactive methods in research, the researcher is already beginning to demonstrate an awareness of the importance for the co-construction of knowledge and a commitment to modest forms of inclusion where greater collaboration is not possible because of, for example, institutional restrictions or only a recent understanding of the potential for research with greater inclusion.

\section{Participatory approaches}

Participatory research can be seen as a modest partnership approach to knowledge production. It 'recognises the value of engaging in the research process those who are intended to be the beneficiaries, users and stakeholders of research' (Cargo \& Mercer 2008:326). Its orientation towards shared power is underscored by a commitment to the democratisation and demystification of scientific research. Research participants (and those from the communities to which they belong) are seen as knowledgeable collaborators. Subsequently, the research agenda, design and the dissemination of its outcomes are planned jointly (although still along a continuum of influence). Its underlying virtues include mutual respect and trust, accountability, reflexivity and dialogue. Recalling the different modes of participation articulated by Biggs (1989), the mode of participation envisioned in this part of the continuum lies between collaborative and collegiate, and ownership is shared. Fundamentally, the researcher asks participants what they want from the research process and from researchers, rather than assuming what they need.

\section{Emancipatory research}

The transition from participatory to emancipatory research sees a progressive departure from research as a partnership
TABLE 1: Comparing and contrasting interactive, participatory and emancipatory approaches.

\begin{tabular}{|c|c|c|c|}
\hline Variable & Interactive & Participatory & Emancipatory \\
\hline Knowledge & \multicolumn{3}{|c|}{$\begin{array}{l}\text { A commitment to applied knowledge and the co-construction of } \\
\text { knowledge }\end{array}$} \\
\hline Learning & \multicolumn{3}{|c|}{$\begin{array}{l}\text { A commitment to mutual and sustainable learning, self-reflection } \\
\text { and the empowerment of research participants }\end{array}$} \\
\hline $\begin{array}{l}\text { Inclusion and } \\
\text { power }\end{array}$ & $\begin{array}{l}\text { Slight inclusion; } \\
\text { shared power on } \\
\text { researcher's terms }\end{array}$ & $\begin{array}{l}\text { Modest inclusion; } \\
\text { shared power }\end{array}$ & $\begin{array}{l}\text { Complete inclusion } \\
\text { (or partnership on } \\
\text { participants' terms); } \\
\text { researcher } \\
\text { relinquishes power }\end{array}$ \\
\hline $\begin{array}{l}\text { Research } \\
\text { agenda }\end{array}$ & $\begin{array}{l}\text { Research agenda is } \\
\text { predetermined }\end{array}$ & $\begin{array}{l}\text { Research agenda } \\
\text { is developed } \\
\text { through } \\
\text { consultation }\end{array}$ & $\begin{array}{l}\text { Participants choose } \\
\text { research agenda, } \\
\text { enlist services of } \\
\text { researcher }\end{array}$ \\
\hline $\begin{array}{l}\text { Research } \\
\text { design }\end{array}$ & $\begin{array}{l}\text { Research is already } \\
\text { designed when } \\
\text { research commences }\end{array}$ & $\begin{array}{l}\text { Joint planning of } \\
\text { design }\end{array}$ & $\begin{array}{l}\text { Design is initiated } \\
\text { by participants }\end{array}$ \\
\hline Dissemination & $\begin{array}{l}\text { Dissemination is } \\
\text { decided by } \\
\text { researcher }\end{array}$ & $\begin{array}{l}\text { Dissemination is } \\
\text { a shared } \\
\text { responsibility }\end{array}$ & $\begin{array}{l}\text { Participants decide } \\
\text { what is done with the } \\
\text { research findings. }\end{array}$ \\
\hline Authorship & Retained authorship & Joint authorship & $\begin{array}{l}\text { Relinquished } \\
\text { authorship }\end{array}$ \\
\hline Ownership & Research is mine & Research is ours & Research is theirs \\
\hline
\end{tabular}

or collaborative exercise. Instead, the traditional researcher relinquishes power and ownership to the extent that the dichotomy between researcher and researched is collapsed. A researcher may approach a community and offer skills to help determine a research design and agenda, asking 'what do you want to know' or a community can approach a researcher and ask them to serve their concerns. In both cases, the researched ascend to a leadership role in key areas of the research process, such as the definition of topic, data collection, data analysis and dissemination. In relinquishing ownership, the traditional researcher takes on the role of facilitator, putting their skills and expertise at the disposal of marginalised communities, allowing for participants to exercise full ownership of the research.

Table 1 offers a brief summary of the points of convergence between interactive, participatory and emancipatory research along with points of divergence. Key to note is the way in which all approaches share fundamental aims of mutual learning and bringing about the practice of freedom, and how inclusion, power and ownership enact themselves along a broad continuum, with fluid overlaps and intersections. As a result of these characteristics, all three types of inquiry along this continuum can be described as 'research as intervention' (Swartz 2011:50). They are all anchored, albeit to different degrees, on the premise that participants ought to benefit from the research. Each approach thus cultivates an 'intentional ethics of reciprocation' that is mindful of a responsibility to 'give back' (Swartz 2011:49).

\section{Four case studies to explore the research as freedom continuum}

In order to see how such a continuum might be useful to both evaluate current research and design future research, we offer four case studies to explore what we are calling the 'the research as freedom continuum'. We first provide a brief synopsis of each study that includes the core research question, the context of the research participants and notable 
methodological features. We also include a description of how the study included young people's engagement with matters of faith as part of the (in)justice concern.

Ikasi: the moral ecology of South Africa's township youth (Swartz 2009) describes how young black South Africans who grew up in an impoverished community understood and articulated their conceptions and influences of morality. Thirty-seven young men and women, aged 14-20, in a township (favela, barrio and slum) school participated in this study. An ethnographic methodology was employed over the course of 16 months with return visits, involving participant observation, interviews and photovoice in which young people visually documented their moral influences - both good and bad - and explained them to the researcher. For these young people, mothers, faith, friends and alcohol were key amongst their moral influences, although young people had different primary influences depending on whether they were 'mommy's babies', 'right ones', 'kasi [township] kids' or 'skollies' (a colloquial term for gangsters).

Teenage tata: voices of young fathers in South Africa (Swartz \& Bhana 2009) describes what it is like to be a young father in an impoverished community in South Africa by interrogating the obstacles to and enablements of teenage fathering. It involved a sample of 27 teenage fathers in two township communities, as well as the social networks of some of these fathers. The methods used included drawing, storytelling and an innovative methodology called Social Network Interviews (SNIs), which supplemented the data from the two interviews with each young father. The SNIs invited these young fathers to interview parents, extended family, family of the mother of their child, teachers, friends and religious or community leaders according to an intentional set of questions designed to broaden their networks and offer them insight into their situation.

Studying while black: race, education and emancipation in South African universities (Swartz et al. 2018a) describes a 5-yearlong study that problematised the impediments to higher education in South Africa, such as the lack of equity in enrolment and completion between black and white students as an ongoing legacy of apartheid discrimination. It subsequently interrogated the centrality of race in the quest for education and emancipation with a view towards understanding what drives self-determination and success in universities. This involved the participation of 80 students (mostly black) through interviews along with documented experiences through a weblog, SNIs and the crafting of a documentary.

Moral eyes: youth and justice in Cameroon, Nigeria, Sierra Leone and South Africa (Swartz et al. 2018b) problematised the continued effects of historical injustice in relation to identity in four African countries. These identities and countries were race (South Africa), religion and ethnicity (Nigeria), ethnicity (Sierra Leone) and language and geography (Cameroon). Through a conceptual framework of restitution defined as an individual and collective moral responsibility aimed at rehabilitating personhood through recognition, opportunity and belonging, the study asked how best can university students bridge the gap between knowing about privilege and injustice and taking action to disrupt and transform such realities. Seventy-two students from diverse religious, political and educational backgrounds, ranging in age from 18 to 41, were interviewed. Twenty participants were interviewed from each country except in Sierra Leone (where only 12 were interviewed) as a result of an Ebola-enforced travel ban. The study engaged four young researchers (all graduate students), under the guidance of a more experienced researcher, to conduct the study along the principles of coenquiry, design and ownership. It is this aspect of the research, specifically the relationship between the principal investigator and the researchers, that we focus on. Whilst it is also possible to consider how these researchers interacted with the research context itself, we chose to concentrate on the former.

Each of these case studies had strong themes at the intersection of youth marginality and religious faith. In Ikasi, conceptions of morality were often anchored in faith and religion. For example, participants often did not saddle blame for poverty on apartheid, trusting that God is in control of their situation. Teenage tata exposed the shame carried by teenage fathers and their subsequent rejection by the church because they had transgressed so visibly. In the case of Studying while black, the role of faith in consolidating success was emphasised. Finally, Moral eyes revealed similar experiences to Ikasi, where faith was often seen as an antidote to the alienation of historical injustice and its consequences, with much discussion about forgiveness. Furthermore, faith also shaped attitudes to other injustices, as is evident in the study by some of the visceral (and negative) reactions to homosexuality and gender equality.

\section{Evaluating youth research through a freedom continuum}

We considered the interactive, participatory and emancipatory elements of these case studies by considering a number of questions as follows:

1. How have the chosen research activities allowed participants to be engaged and for their voices to be heard polyphonically?

2. What evidence is there of transparency and self-reflection to make clear the researcher's politics of involvement?

3. How has the researcher attempted to develop respect and trust in order to diminish inherent power differences?

4. How have decisions about language and representation contributed to or prevented a colonising discourse?

5. To what extent are participants co-authors in the research, or at least involved in 'member checks'?

6. To what extent are they involved in its dissemination?

7. What commitments have been made to mutuality, 'research-as-intervention' and an intentional ethics of reciprocation? 
8. To what extent have participants been agents, that is, deciding on the problem of their choosing and/or involved in the design of the research?

9. To what extent has space been provided for participants to continue the process of agency and self-emancipation?

10. To what extent has this research been emancipatory and relational rather than dominating and oppressive?

These questions helped us to further operationalise some of the convergences and divergences we noted earlier. Table 2 offers a summary of how each study faired in response to each of these questions with a simple yes or no, although it might be more appropriate to evaluate how these criteria have been met along a, say, 10-point scale in future assessments. It also offers a categorisation on where along the continuum of questions (simply answered as yes or no) a research study may change from interactive to participatory, or from participatory to emancipatory. We suggest that affirmative answers to questions 1-3 characterise interactive research; positive answers to question 1-7 point towards more participatory research, whilst being able to answer 'yes' to all 10 questions makes it likely that research is emancipatory in nature. We are acutely aware that this categorisation is subject to change as we learn more about each of these aspects of the continuum and also debate the boundaries for each. We now turn to how we arrived at these evaluations, considering each study individually and in more detail.

\section{Ikasi: Youth moral influences in a South African township}

Ikasi had a number of interactive methods that allowed for involvement of research participants in the research. These included photovoice, an adventure camp and a rank ordering activity and questionnaire. Participants were asked to take photographs of their moral environment in order to represent the good and bad influences in their lives (Swartz 2009:107ff.). The activity also gave each participant an opportunity to explain how each person, place or action they had taken photographs of affected their moral formation. The rank order activity, which the author described as 'circles of influence', provided information on the strength of these influences. This was done through a drawing activity in which young people were given a large poster with their name in the middle, around which were a series of concentric circles. They were provided a set of labels (which emerged from the photovoice activity) and were asked to place labels in the circles to illustrate the varying intensities of their influences. Labels closest to their names were strongest whilst those farther away were weaker influences. Participants were also provided with blank labels in case they wanted to add influences they had no photographs of. Moreover, they were not compelled to use all the labels provided.

Also observable is the deliberate endeavour to cultivate relationships with the research participants. The author notes that initially, she was largely ignored by the young people at the research site. Subsequently, she increased her presence from 3 days a week to every day, often sitting at the back of classrooms, ensuring that she learned the names of students. This continued presence allowed young people to engage her at their own convenience, and some even offered to teach her isiXhosa to ease her navigation. Relationships with young people was also cultivated through adventure camps and outings dependent on parents' permission, in addition to visiting participants in their homes which increased trust not just with the participants but with their family members as well (Swartz 2011).

Researcher subjectivity was conveyed through a reflection on the author's race, age, class and religious affiliation and how it affected the research experience. For example, religious faith added a 'pastoral dimension' to the research as the author came to be seen as a 'counsellor and confidante' (Swartz 2011:55). However, it caused problems in moments of value-conflict and required the author to deliberately limit evidence of approval or disapproval except in cases of obvious self-harm or the endangerment of others. Another example is the age of the author at the time (in her thirties), which led to participants seeing her as in between mother and friend, rather humorously encapsulated in the moniker 'mommy-buddy' (Swartz 2011).

\section{Berger (2001) notes that:}

$[w]$ hen researchers are open about their own personal stories, participants feel more comfortable sharing information, and the hierarchical gap between researchers and respondents formerly embraced in ethnographic work is closed. (p. 507)

TABLE 2: A comparison of criteria met by each research study.

\begin{tabular}{|c|c|c|c|c|}
\hline Variable & Ikasi & Teenage tata & Studying while black & Moral eyes \\
\hline \multicolumn{5}{|l|}{ Interactive } \\
\hline Appropriate interactive research activities to ensure engagement and polyphonic answers & $\checkmark$ & $\checkmark$ & $\checkmark$ & $\checkmark$ \\
\hline Conveying researcher subjectivity and transparency of research intent & $\checkmark$ & $x$ & $\checkmark$ & $\checkmark$ \\
\hline Deliberately building relationships with research participants to diminish power differences & $\checkmark$ & $x$ & $\checkmark$ & $\checkmark$ \\
\hline \multicolumn{5}{|l|}{ Participatory } \\
\hline Considering how language is used and representations are made & $\checkmark$ & $\checkmark$ & $\checkmark$ & $\checkmark$ \\
\hline Involvement of participants in dissemination & $\checkmark$ & $\checkmark$ & $\checkmark$ & $\checkmark$ \\
\hline Benefits to participants of study & $\checkmark$ & $\checkmark$ & $\checkmark$ & $\checkmark$ \\
\hline \multicolumn{5}{|l|}{ Emancipatory } \\
\hline Deciding on the 'problem' of their choosing and/or research design & $x$ & $\checkmark$ & $x$ & $\checkmark$ \\
\hline Providing the space to continue the process of agency and self-emancipation & $\checkmark$ & $x$ & $\checkmark$ & $\checkmark$ \\
\hline Emancipatory and relational versus dominating and oppressive & $\checkmark$ & $\checkmark$ & $\checkmark$ & $\checkmark$ \\
\hline
\end{tabular}


The cultivation of relationships described earlier had real implications for reallocating power between researcher and respondents, contributing to a flattening of the power gradient. Participants in this study frequently described their rapport with the author as 'free' and 'open' (Swartz 2011:58). The author reflected on the role of money and how spending money on research participants can widen or flatten the power gradient, ultimately deciding that it was better to be perceived as generous with time and food, rather than as a financial paymaster (so no money was given to participants). This was to limit any expectations of reward which would otherwise render the locus of power with the researcher (Swartz 2011:59). In addition, member checks (obtaining and incorporating feedback from respondents into final written outputs) also helped lessen power discrepancies. Participants were given their transcripts to ensure accurate representation and were allowed to comment on the author's field notes as well as to provide their opinion on the emerging analysis (Swartz 2009:182).

The aforementioned member checks, in precluding ventriloquism, also played a role in ensuring that young people 'speak in the own voices and on their own terms' (Swartz 2011:60). Therefore, not only did the member-check strategy diminish power differentials, it also promoted fair representation of respondents. This speaks to the description of participatory research as the co-construction of meaning predicated on interpretation as opposed to domination as its modality (Christians 2005:126). The photovoice activity can also be seen as a project of self-representation. An obstacle to issues of language and representation was the fact that the participants were often second- or third-language English speakers. This, along with the representational challenges of translation, explains the decision not to use verbatim quotations, to avoid unfair representations of the respondents as childish, unsophisticated or unintelligent (Swartz 2011:61). Participants were also involved in the dissemination of some of the research output. They were invited to several book launches (school, community and academy), wherein joint presentations were made.

In discussing evidence of 'research as intervention', one must ask if the research espoused an intentional ethic of reciprocation by giving back, thus ensuring that participants benefitted from the research. Ikasi had multiple forms of intervention, not only for the participants but also for their community of peers and caregivers. Direct intervention took the form of overt advice-giving and referrals for help on issues ranging from sexual health to alcoholism. The author also engaged in whistle-blowing to the school principal about various abuses occurring in school. Listening emerged as a crucial intervention from the perspective of the participants because it embodied a sustained interest in their lives which was often lacking in their social networks. This shows that participatory elements of research, such as the intentional cultivation of relationships, can have emancipatory outcomes. Upon reflection, respondents also noted that participation in the research was cathartic and had introduced a critical consciousness in their lives. With regards to their community of caregivers and peers, parents noted improvements in their children's lives such as increased commitment to their education and self-confidence. Finally, the author has maintained long-term relationships with several students who participated in this study, providing mentorship as well as referring others to potential mentors. This mentoring activity serves to continue the process of agency and selfemancipation.

\section{Teenage tata: Young black fathers in South Africa}

The study on young fathers emerged from the Ikasi study, when it was brought to the author's attention (by participants themselves) that a number of those involved in the study were young teenage fathers and who expressed both a need and an interest in talking about their situation. A core part of this study was therefore a series of two semi-structured interviews where the questions were deliberately openended in order to elicit narratives and reflection. It was hoped that this would provide a space for young fathers to express themselves in ways which were conducive to a deeper understanding of their circumstance and what they might do about it (Swartz \& Bhana 2009:7). Two interactive activities were included in these interviews. The first was akin to the 'circles of influence' activity described in Ikasi. Young fathers were presented with three concentric circles. A small circle in the centre was surrounded by two larger circles. Participants had to place in these circles people involved in the story of them as fathers and their baby as a way of representing the closeness of the relationship. The second interactive instrument was a rank order activity, which required the participants to list three things that helped them be a good father, and three obstacles to fatherhood, in order of priority (Swartz \& Bhana 2009:8).

Whilst co-authorship or participant authorship did not characterise the research output, participants were involved in the dissemination of the research. This took the form of joint presentations at various book launches held at local universities and at nonprofit organisations. Mutuality is evident in the research design as the mode of participation was often consultative and collaborative, thus flattening the power gradient. For example, upon consultation, the idea of video-recorded interviews (for SNIs) was rejected because of fraught relationships with family members. Another instance of mutuality is observable in the third phase of the study, which involved an afternoon debrief and consultation workshop. This workshop was significant as an instance of member-checking because it was an opportunity for participants to comment on whether they had been fairly and accurately represented. This process also illustrated the co-construction of knowledge as each chapter was discussed (after being read, summarised and translated into isiXhosa by a community informant), with a wide range of agreement and disagreement. For example, Chapter 6, which deals with participants' lack of condom use and multiple concurrent partnerships, was perceived as representing them negatively. 
At the same time, they acknowledged that this was an important part of the research as it illustrated accurately life in the townships, their irresponsibility and what drives them to act as they do (Swartz \& Bhana 2009:17). After a long discussion, the young men agreed that it should stay as part of the research output, but that some amendments should be made, and further explanations added about, for example, the way in which poverty keeps one from parading expensive possessions, but that having multiple partners met this same need for recognition.

This workshop also dovetailed with research as intervention. It was an opportunity for these young fathers to all meet and possibly form informal peer networks which might help them in their roles as fathers (Swartz \& Bhana 2009:17). In so doing, it provided a space to continue the process of agency and self-emancipation. Furthermore, research as intervention was most clearly visible in the SNIs conducted. Young fathers were invited to interview eight members of their social networks. These could include their mother, father, mother of their child, her parents, sibling, teacher, community leader, youth leader, grandparent, etc. The authors describe the process in this study as follows (Swartz \& Bhana 2009):

Social network interview questions begin by allowing the respondent to recall the occasion and reflect on their response and advice at the time. [The next questions] ... allow respondents to evaluate young fathers' performance and invite constructive criticism. Although uncomfortable for young fathers, these questions assist in building the relationship and establishing rapport. [The following question] ... proceeds to a specific analysis of the role of culture (both positive and negative) in young fatherhood, while [the final three] questions ... return to more constructive advice for young fathers - including a dispassionate analysis of why young fathers lose contact with their children over time. (p. 101)

The emancipatory potential of SNIs resides in its capacity to strengthen and support young men in their role as fathers. In addition to providing rich data about the lives of these fathers, it was a collaborative learning process about their own behaviour and circumstances because it provided a space whereby corrective messages could be heard (i.e. how to be a better father). For example, a close male friend of one of the young fathers noted (Swartz \& Bhana 2009):

As your closest friend, uh, because I've been spending a lot of time with you - [ I can see that $]$ you don't take care of your baby. You're very - sometimes you become irresponsible - you're [with your new girlfriend] instead of doing what you must do to keep contact with your baby. (p. 104)

Moreover, it contributed to the building of closer ties and empathetic relationships with their networks and those of the mother of their child. The authors argue that it led, on the part of the fathers, to a 'desire to expand and deepen their relationship with the mother of their child as well as her family and social network' (Swartz \& Bhana 2009:103). Finally, the activity was empowering, inasmuch as it returned power to make autonomous choices. As a result of the SNIs, young fathers could process corrective feedback and plan for future involvement in their children's lives (Swartz \& Bhana 2009:105).

\section{Studying while black: Education and emancipation at university}

This study had a number of interactive methods which had outcomes typically associated with participatory and emancipatory inquiries. The activities in this study included annual participant interviews, SNIs, a Facebook weblog over the course of 5 years, a written reflection at the end of the fifth year and an auto-ethnographic documentary in which participation was optional (Swartz et al. 2018a).

An important observation from the research regards the emancipatory potential of SNIs. SNIs helped to create networks through peer conversations and interaction with supportive adults and university personnel. SNIs embodied an intentional ethic of reciprocation by giving back to the participants and encouraging behavioural changes. Participants were empowered through identifying with and gaining motivation from the stories of others. This resulted in thinking and doing things differently. One example includes the encouragement to make use of services on campus. Students also received advice on how to interact with lecturers, which had a concrete impact, for example, in terms of gaining courage to ask questions in class. Ultimately, SNIs expanded participants' social and cultural capital such as their grasp of the 'rules of the game' and what has been coined the 'hidden curriculum' (Swartz et al. 2018a).

This study was also characterised by intentional efforts to build relationships with research participants. Participants frequently spoke of how motivating it was to see a researcher a couple of times a year and to be in touch with them by phone or text regularly, every year for 5 years. Many spoke of feeling that someone was 'checking up' on them or 'watching over' them which spurred them on to do their best. Researchers (and the research design) also made intentional efforts to cultivate friendships between research participants (both on their own campus and on other campuses) and did so primarily through the Facebook weblog. These relationships underpinned much of the emancipatory outcomes identified earlier. Similar to the SNIs, the Facebook weblog created a sense of community and comfort and a space where participants engaged in mutual problem sharing and the development of strategies to solve these problems. This is significant in the extent to which it embodies Paolo Freire's vision of emancipatory problem-solving research (2000:79-81). Moreover, the sense of community was anchored in the fact that the Facebook weblog was of therapeutic value, providing a space to offload emotionally. As a testament to the interventionist value of this activity, participants requested that the Facebook group stay open beyond the project's duration (Swartz et al. 2018a). This highlights the group's potential in providing a space to continue the process of agency and self-emancipation. 
Whilst there is no co-authorship in terms of research output, there are plans to present this research at all universities in South Africa (and many schools), where participants will be part of the presentations made. The documentary is a key tool of dissemination, already accessible and freely available on social media. Many participants have already asked if they might take the documentary to their home towns and show it to the schools from where they had come. Finally, there is clear evidence of a commitment to consider how language is used and representations are made, not only in the final outputs (book and documentary) but also as questions were re-asked over the years in order to allow polyphonic hearing. The Facebook weblog, as well as the auto-ethnographic documentary were also conducive to selfrepresentation.

\section{Moral eyes: Youth and justice in four African countries}

In this study of youth justice, we focus on the relationship between an experienced researcher and novice researchers who conducted research in each of four African countries, as well as the process of the research study. Whilst the lead researcher had the idea to conduct comparative research on the possibilities for restitution in four African countries, and selected researchers from these countries, there is still evidence of agents deciding on the problem of their choosing. The researchers were from Cameroon, Nigeria, Sierra Leone and South Africa and made the decision on which identities would constitute the lens through which privilege and oppression were viewed. For example, the lead researcher initially wanted to look at sexuality and the repression of LGBT rights in Cameroon, but was told by the context researcher that the intersection of language, geography and ethnicity represented the main fault line for privilege and injustice. Recent social unrest in Cameroon bears testament to this. Of all the case studies therefore, Moral eyes came closest in terms of agents deciding on a problem of their choosing as it empowered young researchers to understand oppression in their contexts with a view towards transforming it. Given that these agents were also the core research team, they were inevitably involved in decisions around research design. These features speak to the aspiration in emancipatory inquiry where those affected by oppression initiate and steer the research, with facilitation from the traditional researcher (in this case the lead researcher).

Prior to conducting fieldwork, the context researchers reflected on what would render them better or poorer researchers, showing an awareness of the need to reflect on researcher subjectivity. For example, the context researcher for South Africa was white and reflected on how that positionality would trigger black participants, especially in emotive narratives of 'black pain'.

Throughout the research journey, a number of factors reflected the intentional cultivation of relationships between the principal investigator and researchers. It is worth noting that there were already existing relationships between these members as the lead researcher had lectured and supervised the members of the research team. In order to build on these relationships, the research team met with the lead researcher every second Friday over the course of 2 years. They also travelled together to Brazil and the United States, where they presented at two international conferences and had a writing workshop in the tranquillity of a nearby coastal town. These activities contributed to nurturing a community of inquiry. Furthermore, the researchers continue to benefit from the mentorship of the lead researcher, thus providing an opportunity to continue the process of agency and selfemancipation. These relationships helped to develop mutuality and flatten the power gradient between the lead researcher and the researchers. In their absence, one could easily have been overwhelmed by the leadership of the lead researcher who is an experienced academic. Furthermore, financial decisions also contributed to this mutuality. Despite their inexperience, the researchers were paid what established researchers would make, thus contributing to a sense of genuine collaboration and equity. A similar point is made in the peace-building literature, where practitioners note the wage discrepancy between international and local practitioners to imply a hierarchy between local and international expertise.

The research equally functioned as intervention, in the sense that the context researchers benefitted from the study. Given their inexperience, their research capacities were enhanced through the mentorship of the lead researcher, coupled with their participation at international conferences. These conferences were also an opportunity to create networks with scholars across the globe, thus benefitting from diverse perspectives on similar subject matter. In terms of authorship and dissemination, the lead researcher and the research team are co-authors in the resulting book publication and forthcoming peer-reviewed journal article which described the findings of the study. Furthermore, there has been joint dissemination of the research at local and international conferences and seminars.

Finally, issues of language and representation were catered for through member-checking, which was a function of the intimacy the researchers had in the research process. Each member had to write a summary of their country findings grouped in various themes. After this, each member was assigned a number of thematic chapters across the different country contexts. Meeting so regularly precluded misrepresentations. Writing on themes across the different country contexts also benefitted the individual researchers as it improved their knowledge on contexts they were otherwise unfamiliar with. This has resonance within a global moment that calls for knowledge production from the South about the South, where it is just as important for Southern scholars to know about the South as it is for their Northern peers.

\section{Concluding implications}

The preceding discussion allowed us to place each of four research studies that investigated young people's marginality 
in various forms along the continuum of interactive, participatory and emancipatory research. As the Figure 2 suggests, emancipatory research represents the locus of aspiration for research as freedom, and as such it is the ultimate goal.

Whilst a number of emancipatory outcomes were observable, none of these case studies were fully emancipatory, as they were initiated and led by the researcher despite attempts to flatten the power gradient and give back (one interpretation of the research process in Moral eyes comes closest in this regard). This is not necessarily a problem, as researchers will always have to negotiate when and how emancipation or research as freedom is possible.

In offering an analysis of the continuum along which interactive, participatory and emancipatory inquiries may be placed in critical qualitative research, a number of implications and limitations emerge. Firstly, as researchers, if we are committed to research that changes people's lives and brings about freedom, we need to take seriously all elements of the continuum of inquiry including engagement, empowerment and mutuality. To achieve this, research must necessarily be both interactive and participatory at a minimum (see Figure 2). That said, interactive methods alone, as we have defined it, whilst allowing for polyphonic voices and parallax perspectives, fail to involve participants sufficiently. We must therefore choose interactive activities capable of translating into future participatory and emancipatory outcomes. Furthermore, if our ultimate goal remains freedom and emancipation, we have to think deeply about the following two questions: What will it take in our own practices to invite participants to set their own research agendas and what is needed to create a space for selfemancipation after the research process is over?

Secondly, we also need to re-evaluate methods previously assumed to be participatory because they might simply be interactive. From our analysis, it is possible to place what has

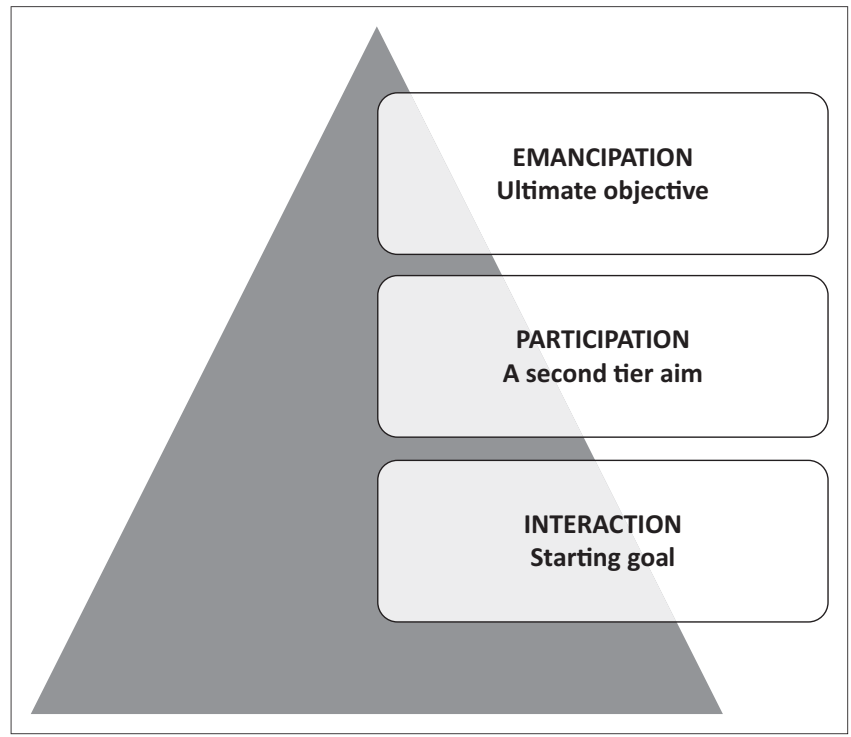

FIGURE 2: Goals of research as freedom in stages. been considered participatory methods, such as photoelicitation, photovoice, community mapping and SNIs, into either interactive or participatory categories because the criteria for participation depend not so much on the method as the intent. In order to transcend the interactive label and attain the participation label, we ought to link these methods to gains in ownership and empowerment. We must reflect on these methods to consider how they not only allow for parallax perspectives but also provide an opportunity for research as intervention, and more broadly their role in promoting research that puts participants at the centre of transforming their marginality. Many of these engaging methods may also be emancipatory if ownership and power are employed as a criteria for their use instead of merely their engaging nature.

Thirdly, future research need not restrict this kind of analysis to the domain of methodological practices as we have done. An unfortunate consequence of the methodological focus is the absence of a deeper reflection around the actual knowledge produced in these case studies and how participants benefitted from it. That is, whilst we assessed varying methodological practices in relation to the continuum, it was not accompanied by a similar reflection on how the knowledge produced situated these case studies along the continuum. This task can be incorporated in future evaluations.

Fourthly, researchers must also help those who fund, monitor and participate in research to understand the purpose of these varying kinds of research. Research as freedom necessarily breaks the chain of research for the sake of research, and even further disrupts the idea of the researcher as the most important in the endeavour. This requires efforts at educating funders of research, those in our academic institutions who oversee and reward research according to other criteria and our ethical review boards who may not understand the iterative nature of research as freedom. Getting the academic hierarchy to see the importance of situating research along a continuum that culminates in emancipation is pivotal to consolidating the structural conditions for such research. Furthermore, research participants themselves might need to be helped to see the potential of emancipatory research and aided to develop skills to begin to set their own research agendas and to be able to resist having research imposed upon them.

Finally, this analysis has implications for consumers of research. It offers tools to reflect on whether research that purports to promote freedom in fact does so. It challenges those who use or encourage research to ask how this approach could be institutionalised, expected or even demanded. Finally, in the field of theology, where conventionally scant attention has been given to research methods generally, beyond hermeneutical issues of meaning and interpretation, employing such a proposed continuum of research, with its end goal of freedom, emancipation and justice has much to offer. Young people, in South Africa, on the African continent, 
and in the global South more broadly, are immersed in questions, issues and experiences of faith. Using this continuum as an evaluative tool will aid theological researchers to address youth marginality as an issue of faith, interrogate methods as an issue for faith communities and researchers and expect research as freedom to become the ultimate ideal for faith-based researchers.

\section{Acknowledgement Competing interests}

The authors declare that they have no financial or personal relationships which may have inappropriately influenced them in writing this article.

\section{Authors' contributions}

S.S. was the lead author, built the intellectual structure and derived the primary outputs. A.N. did the literature review and was the co-writer and collaborator.

\section{References}

Albinsson, G. \& Arnesson, K., 2010, 'How critical can you be as an on-going evaluator?', International Journal of Action Research 6(2/3), 256-287. https://doi. org/10.1688/1861-9916_IJAR_2010_02-03_Albinsson

Aldridge, J., 2015, Participatory research: Working with vulnerable groups in research and practice, Policy Press, Bristol, UK.

Alexander, I.M., 2010, 'Emancipatory actions displayed by multi-ethnic women: "Regaining control of my health care"', Journal of the American Academy of Nurse Practitioners 22(11), 602-611. https://doi.org/10.1111/j.1745-7599. 2010.00554.x

Amble, N., 2012, 'Reflection in action with care workers in emotion work', Action Research 10(3), 260-275. https://doi.org/10.1177/1476750312443572

Amendola, M.G., 2011, 'Empowerment; Healthcare professionals' and community members' contributions', Journal of Cultural Diversity 18(3), 82-89.

Astleithner, F. \& Hamedinger, A., 2003, 'The analysis of sustainability indicators as socially constructed policy instruments: Benefits and challenges of interactive research', Local Environment 8(6), 627-640. https://doi.org/10.1080/ 1354983032000152734

Baker, J., Lynch, K., Cantillon, S. \& Walsh, J., 2004, Equality: From theory to action, Palgrave Macmillan, New York.

Bangdiwala, S.I., Villaveces, A., Garrettson, M. \& Ringwalt, C, 2012, 'Statistical methods for designing and assessing the effectiveness of community-based interventions with small numbers', International Journal of Injury Control and Safety Promotion 19(3), 242-248. https://doi.org/10.1080/17457300.2012. 704050

Berger, L., 2001, 'Inside out: Narrative autoethnography as a path toward rapport' Qualitative Inquiry 7(4), 504-518. https://doi.org/10.1177/107780040100700407

Biggs, S., 1989, Resource-poor farmer participation in research: A synthesis of experiences from nine national agricultural research systems, International Service for National Agricultural Research, The Hague, Netherlands.

Boog, B.W., 2003, 'The emancipatory character of action research, its history and the present state of the art', Journal of Community \& Applied Social Psychology 13(6), 426-438. https://doi.org/10.1002/casp.748

Cargo, M. \& Mercer, S.L., 2008, 'The value and challenges of participatory research: Strengthening its practice', Annual Review of Public Health 29, 325-350. https:// doi.org/10.1146/annurev.publhealth.29.091307.083824

Christians, C., 2005, 'Ethics and politics in qualitative research', in N. Denzin \& Y. Lincoln (eds.), The Sage handbook of qualitative research, 3rd edn., pp. 133-55, Sage, London, UK.

Cook, J.A. \& Fonow, M.M., 1986, 'Knowledge and women's interests: Issues of epistemology and methodology in feminist sociological research', Sociological Inquiry 56(1), 2-29. https://doi.org/10.1146/annurev.publhealth.29.091307. 083824

Cook, W.K., 2008, 'Integrating research and action: A systematic review of communitybased participatory research to address health disparities in environmental and occupational health in the USA', Journal of Epidemiology \& Community Health 62(8), 668-676. https://doi.org/10.1136/jech.2007.067645

Cornwall, A. \& Jewkes, R., 1995, 'What is participatory research?', Social Science \& Medicine 41(12), 1667-1676.

Danieli, A. \& Woodhams, C., 2005, 'Emancipatory research methodology and disability: A critique', International Journal of Social Research Methodology 8(4), 281-296. https://doi.org/10.1080/1364557042000232853
De las Nueces, D., Hacker, K., DiGirolamo, A. \& Hicks, L.S., 2012, 'A systematic review of community-based participatory research to enhance clinical trials in racial and ethnic minority groups', Health Service Research 47(3 Pt 2), 1363-1386. https:// ethnic minority groups', Health Service Resear
doi.org/10.1111/j.1475-6773.2012.01386.x

Freire, P., 2000, Pedagogy of the oppressed, Bloomsbury, New York.

Garbutt, R., 2009, 'Let's talk about sex: Using drama as a research tool to find out the views and experiences of young people with learning disabilities', Creative Approaches to Research 2(1), 8-21. https://doi.org/10.3316/car0201008

Gustavsson, M., 2009, 'Facilitating expansive learning in a public sector organization', Studies in Continuing Education 31(3), 245-259. https://doi.org/ 10.1080/01580370903271453

Hart, R.A., 1992, Children's participation from tokenism to citizenship, UNICEF Innocenti Research Centre, Florence, Italy.

Irwin, L., 2006, 'The potential contribution of emancipatory research methodologies to the field of child health', Nursing Inquiry 13(2), 94-102. https://doi.org/10.1111/ j.1440-1800.2006.00308.x

Jagosh, J., Macaulay, A., Pluye, P., Salsberg, J., Bush, P.L., Henderson, J. et al., 2012, Uncovering the benefits of participatory research: Implications of a realist review for health research and practice', Milbank Quarterly 90(2), 311-346. https://doi. org/10.1111/j.1468-0009.2012.00665.x

Jagosh, J., Pluye, P., Macaulay, A.C., Salsberg, J., Henderson, J., Sirett, E. \& Green, L.W., 2011, Assessing the outcomes of participatory research: Protocol for identifying, selecting, appraising and synthesizing the literature for realist review', Implementation Science 6(1), 8. https://doi.org/10.1186/1748-5908-6-24

Kagan, P., Smith, M., Cowling, R. \& Chinn, P., 2009, 'A nursing manifesto: An emancipatory call for knowledge development, conscience, and praxis', Nursing Philosophy 11, 67-84. https://doi.org/10.1111/j.1466-769X.2009.00422.x

Kelly, R. \& Moles, R., 2002, 'The development of local agenda 21 in the mid-west region of Ireland: A case study in interactive research and indicator development', Journal of Environmental Planning and Management 45(6), 889-912. https://doi. org/10.1080/0964056022000024398

Macdonnell, J.A., 2011, 'Gender, sexuality and the participatory dimensions of a comparative life history policy study', Nursing Inquiry 18(4), 313-324. https://doi. org/10.1111/j.1440-1800.2011.00524.x

Maginess, T., 2010, 'Medium as message: Making an 'emancipating' film on mental health and distress', Educational Action Research 18(4), 497-515. https://doi.org/ 10.1080/09650792.2010.524823

Mitchell, C., 2008, 'Getting the picture and changing the picture: Visual methodologies and educational research in South Africa', South African Journal of Education 28(3), 365-383.

Nadimpalli, S.B. \& Hutchinson, M.K., 2012, 'An integrative review of relationships between discrimination and Asian American health', Journal of Nursing Scholarship 44(2), 127-135. https://doi.org/10.1111/j.1547-5069.2012.01448.x

Nugus, P., Greenfield, D., Travaglia, J. \& Braithwaite, J., 2012, 'The politics of action research: 'If you don't like the way things are going, get off the bus', Social Science and Medicine 75(11), 1946-1953. https://doi.org/10.1016/j. socscimed.2012.06.024

Oliver, M., 1992, 'Changing the social relations of research production?', Disability, Handicap \& Society 7(2), 101-114. https://doi.org/10.1080/02674649266780141

Oliver, M., 1997, 'Emancipatory research: Realistic goal or impossible dream?', in C. Barnes \& G. Mercer (eds.), Doing disability research, pp. 15-31, The Disability Press, Leeds, UK.

Rose, J. \& Glass, N., 2008, 'The importance of emancipatory research to contemporary nursing practice', Contemporary Nurse 29, 8-22. https://doi.org/10.5172/ conu.673.29.1.8

Salimi, Y., Shahandeh, K., Malekafzali, H., Loori, N., Kheiltash, A., Jamshidi, E. et al., 2012, 'Is Community-based Participatory Research (CBPR) useful? A systematic review on papers in a decade', International Journal of Preventive Medicine 3(6), 386-393.

Svensson, L., Eklund, J., Randle, H. \& Aronsson, G., 2007, 'Interactive research- an attempt to analyse two change programmes', International Journal of Action Research 3(3), 250-277.

Swartz, S., 2009, Ikasi: The moral ecology of South Africa's township youth, Wits University Press, Johannesburg, South Africa.

Swartz, S., 2011, “Going deep" and "giving back": Strategies for exceeding ethical expectations when researching amongst vulnerable youth', Qualitative Research 11(1), 47-68. https://doi.org/10.1177/1468794110385885

Swartz, S. \& Bhana, A., 2009, Teenage tata: Voices of young fathers in South Africa, Human Sciences Research Council, Cape Town, South Africa.

Swartz, S., Mahali, A., Moletsane, R., Arogundade, E., Khalema, N.E., Cooper, A. et al., 2018a, Studying while black: Race, education and emancipation in South African universities, HSRC Press, Cape Town, South Africa.

Swartz, S., Nyamnjoh, A., Arogundade, E., Breakey, J. \& Bockarie, A., 2018b, Moral eyes: Youth and justice in Cameroon, Nigeria, Sierra Leone and South Africa, HSRC Press, Cape Town, South Africa.

Walmsley, J., 2001, 'Normalisation, emancipatory research and inclusive research in learning disability', Disability \& Society 16(2), 187-205. https://doi.org/ 10.1080/09687590120035807

Watts, J., 2006, 'The outsider within: Dilemmas of qualitative feminist research within a culture of resistance', Qualitative Research 6(3), 385-402. https://doi org/10.1177/1468794106065009

Zarb, G., 1992, 'On the road to Damascus: First steps towards changing the relations of disability research production', Disability, Handicap \& Society 7(2), 125-138. https://doi.org/10.1080/02674649266780161 